Problems in Internal Medicine. W. B. Saunders Co., Philadelphia.

SHEARN, M.A. (1973) Sjögren's syndrome. Seminars in Arthritis and Rheumatism, 2 (4), 165.

ShEARN, M.A. \& TU, W.H. (1965) Nephrogenic diabetes insipidus and other defects of tubular function in Sjögren's syndrome. American Journal of Medicine, 39, 312.

Shioj, R., Furuyama, T., Onodera, S., Saito, H., Ito, H. \& SASAKI, Y. (1970) Sjögren's syndrome and renal tubular acidosis. American Journal of Medicine, 48, 456.
SteinberG, A.D. \& TAlal, N. (1971) Coexistence of Sjögren's syndrome and systemic lupus erythematosus. Annals of Internal Medicine, 74, 55.

Talal, N., Zisman, E. \& Schur, P.H. (1966) Renal tubular acidosis, glomerular nephritis and immunological factors in Sjögren's syndrome. Arthritis and Rheumatism, 11 (6), 774.

Tu, W.H., Shearn, M.A., Lee, J.C. \& Hopper, J. (1968) Interstitial nephritis in Sjögren's syndrome. Annals of Internal Medicine, 69, 1163.

\title{
Transient hypercalcaemia following acute renal failure
}

\author{
C. W. G. TURTON \\ M.B., M.R.C.P.
}

E. J. LEESE

M.B., M.R.C.P.

Department of Medicine, St George's Hospital, London, SW17

\section{Summary}

Two patients with transient hypercalcaemia during recovery from acute renal failure are described. The literature is reviewed and possible pathophysiological mechanisms discussed. Patients with renal failure following muscle damage should have regular measurement of plasma calcium.

\section{Introduction}

Hypercalcaemia is well recognized in untreated chronic renal failure and following haemodialysis and renal transplantation. The subject has been reviewed by Goldsmith, Johnson and Arnaud (1974) but hypercalcaemia in acute renal failure was not mentioned. Transient hypercalcaemia following acute renal failure was first described by Tavill et al. (1964) and since then there have been further reports (Butikofer and Molleyres, 1968; De Morgan and Waterhouse, 1968; Gossman and Lange, 1968; Segal, Miller and Moses, 1968; Turkington et al., 1968; Leonard and Eichner, 1970; Leonard and Nelms, 1970; Grunfeld et al., 1972; Wu et al., 1972; Wilson et al., 1973; Grossman et al., 1974; Lynn, 1975). The highest plasma calcium recorded is $17.2 \mathrm{mg} \%(4.3 \mathrm{mmol} / \mathrm{l})$ by Gossman and Lange (1968) and the longest period of hypercalcaemia was 25 days (Turkington et al., 1968). There is a striking association with muscle damage, seventeen of the nineteen patients previously described having skeletal muscle damage of some type before renal failure. In the two remaining cases (Turkington, et al., 1968) no cause for renal failure was identified.

Correspondence: Dr C. W. G. Turton, Cardiothoracic Institute, Fulham Road, London SW3 6HP.
In fourteen cases, hypercalcaemia occurred during the diuretic phase.

\section{Case 1}

A 23-year-old male chronic schizophrenic took an overdose of trifluoperazine and had two grandmal seizures before admission to another hospital. The following day he had apparently recovered and the blood urea was $8.3 \mathrm{mmol} / \mathrm{l}$. Twelve days later he presented with abdominal pain and vomiting, and was found to have generalized oedema. The urine contained a trace of protein and numerous red cells. The haemoglobin was $14.0 \mathrm{~g} / \mathrm{dl}$; plasma urea 94.6 $\mathrm{mmol} / \mathrm{l}$; creatinine $2334 \mathrm{mmol} / \mathrm{l}$; sodium $121 \mathrm{mmol} / \mathrm{l}$; potassium $7.4 \mathrm{mmol} / 1$; bicarbonate $13 \mathrm{mmol} / \mathrm{l}$; calcium $1.67 \mathrm{mmol} / \mathrm{l}$; phosphate $3.38 \mathrm{mmol} / \mathrm{l}$; alkaline phosphatase $5 \mathrm{KAu}$; total proteins $66 \mathrm{~g} / 1$; albumin $31 \mathrm{~g} / \mathrm{l}$. Peritoneal dialysis was undertaken for 3 days. Renal function rapidly improved, the lowest daily urine output being $0.8 \mathrm{l}$. An intravenous urogram on the fifth day was normal. On the seventh day, the plasma calcium was $2.95 \mathrm{mmol} / \mathrm{l}$ and phosphate 1.90 $\mathrm{mmol} / \mathrm{l}$. By the ninth day the calcium was 3.85 $\mathrm{mmol} / \mathrm{l}$ and phosphate $1.92 \mathrm{mmol} / \mathrm{l}$. Sodium cellulose phosphate ( $20 \mathrm{~g}$ daily) was given orally for 3 days to reduce calcium absorption. The plasma calcium fell steadily to $2.62 \mathrm{mmol} / \mathrm{l}$, phosphate $0.68 \mathrm{mmol} / \mathrm{l}$ and alkaline phosphatase $11 \mathrm{KAu}$, on the fifteenth day. On the sixteenth day, plasma parathyroid hormone (PTH) was $<0.1 \mu \mathrm{g} / 1$ [normal range, up to $0.73 \mu \mathrm{g} / \mathrm{l}$. The assay is insensitive for low and normal levels]. He had no corneal calcification. At 6 weeks all biochemistry was normal. 


\section{Case 2}

A 31-year-old male drug addict developed severe pain in the right leg after injecting a solution of methylphenidate tablets into the right femoral artery. On admission 3 weeks later he complained of painful swelling of the right leg and vomiting. He was dehydrated and had a swollen, hot, tender right thigh, and a right foot drop. Urinalysis was normal and no myoglobin was detected. The haemoglobin was $11.5 \mathrm{~g} / \mathrm{dl}$; plasma urea $50.8 \mathrm{mmol} / \mathrm{l}$; creatinine $2.50 \mathrm{mmol} / \mathrm{l}$; sodium $130 \mathrm{mmol} / \mathrm{l}$; potassium 3.9 $\mathrm{mmol} / \mathrm{l}$; bicarbonate $19 \mathrm{mmol} / 1$; calcium $2 \cdot 50 \mathrm{mmol} / 1$; phosphate $2.55 \mathrm{mmol} / \mathrm{l}$; total proteins $75 \mathrm{~g} / \mathrm{l}$; albu$\min 31 \mathrm{~g} / \mathrm{l}$; alkaline phosphatase $7 \mathrm{KAu}$. X-ray of the right thigh showed extensive linear calcification in all muscles. The patient improved rapidly with conservative treatment and was never oliguric. On the twelfth day the plasma calcium was $3.32 \mathrm{mmol} / \mathrm{l}$; phosphate $1.49 \mathrm{mmol} / \mathrm{l}$; alkaline phosphatase 13 $\mathrm{KAu}$. By the nineteenth day the plasma calcium was normal but the alkaline phosphatase had risen to 28 $\mathrm{KAu}$; plasma PTH was $<0 \cdot 1 \mu \mathrm{g} / \mathrm{l}$. Considerable resolution of soft tissue calcification had occurred. At 6 weeks all biochemistry was normal.

\section{Discussion}

The cause of renal failure in case 1 is uncertain. The overdose must have played some part, but hypotension was not recorded. The convulsions are of interest as one of the patients with McArdle's syndrome reported by Grunfeld et al. (1972) developed myoglobinuria and renal failure following a grand-mal seizure. Renal failure in case 2 probably followed rhabdomyolysis, although myoglobinuria was not detected at presentation.

The cause of hypercalcaemia in these patients is not fully understood but probably results from the fortuitous association of several factors. The association with muscle damage, which is almost absolute, suggests a causal relationship. Grossman et al. (1974) postulated that muscle damage results in an endogenous phosphate load predisposing to tissue deposition of calcium phosphate. When the plasma phosphate falls during the diuretic phase this tissue calcium phosphate might be mobilized. In case 1 the plasma phosphate fell from $3.4 \mathrm{mmol} / \mathrm{l}$ to 1.92 $\mathrm{mmol} / \mathrm{l}$ while the plasma calcium was rising. In case 2 and in those reported by Butikofer and Molleyres (1968) and Gossman and Lange (1968), hypercalcaemia coincided with radiological resolution of soft tissue calcification.

There is good evidence for hyperparathyroidism in acute renal failure in humans (Kovithavongs, Becker and Ing, 1972) and in dogs with experimentally induced renal failure (Bergdahl and Boquist, 1973). Plasma PTH levels in the two patients were measured late and were normal, but inappropriate elevation with respect to plasma calcium was found in the patients described by Leonard and Eichner (1970) and Wu et al. (1972).

A further factor might be rapid and inappropriate increase in renal synthesis of 1,25-dihydroxycholecalciferol, the active vitamin $\mathrm{D}$ metabolite, as the kidneys recover.

Serial assessment of calcium and phosphate balance, PTH levels, and vitamin D metabolism are required to elucidate the pathogenesis of this condition. It is important to recognize the phenomenon as it may be associated with confusion, lethargy, weakness, vomiting, constipation. conjunctival irritation with calcium deposition, and cardiac dysrhythmias. Patients with renal failure following muscle damage should, therefore, have regular measurement of plasma calcium. Parathyroid surgery is clearly inappropriate as hypercalcaemia is always transient and can be controlled medically.

\section{Acknowledgments}

We thank Professor H. P. Lambert, Dr J. D. Maxwell, and Dr P. Richards for permission to report cases under their care and for helpful criticism.

\section{References}

Bergdahl, L. \& Boquist, L. (1973) Hyperparathyroidism in transient experimental renal failure in dogs. Pathologia europaea, 8, 89.

Butikofer, E. \& Molleyres, J. (1968) Akute ischämische Muskelnekrosen, reversibel Muskelverkalkungen und sekundare Hypercalciämie bei akuter Anurie. Schweizerische Medizinische Wochenschrift, 98, 961.

De Morgan, N.P. \& Waterhouse, C. (1968) A case of tertiary hyperparathyroid crisis. American Journal of the Medical Sciences, 256, 322.

Goldsmith, R.S., Johnson, W.J. \& ARnaud, C.D. (1974) The hyperparathyroidism of renal failure: pathophysiology and treatment. Clinics in Endocrinology and Metabolism, 3, 305.

Gossman, H.H. \& LANGe, H. (1968) Hypercalcemia in acute renal failure. Annals of Internal Medicine, 69, 1332.

Grossman, R.A., Hamilton, R.W., Morse, B.M., Penn, A.S. \& GoldberG, M. (1974) Nontraumatic rhabdomyolysis and acute renal failure. New England Journal of Medicine, 291, 807.

Grunfeld, J.-P., Ganeval, D., Chanard, J., Fardeau, M. \& DREYFus, J.-C. (1972) Acute renal failure in McArdle's disease. New England Journal of Medicine, 286, 1237.

Kovithavongs, T., Becker, F.O. \& ING, T.S. (1972) Parathyroid hyperfunction in acute renal failure. Nephron, $9,349$.

LeONARD, A. \& Nelms, R.J. (1970) Hypercalcemia in diuretic phase of acute renal failure. Annals of Internal Medicine, 73, 137.

LEONARD, C.D. \& EICHNER, E.R. (1970) Acute renal failure and transient hypercalcemia in idiopathic rhabdomyolysis. Journal of the American Medical Association, 211, 1539.

LYNN, K.L. (1975) Acute rhabdomyolysis and acute renal failure after intravenous self-administration of peanut oil. British Medical Journal, 4, 385.

Segal, A.J., Miller, M. \& Moses, A.M. (1968) Hypercalcemia during the diuretic phase of acute renal failure. Annals of Internal Medicine, 68, 1066. 
Tavill, A.S., Evanson, J.M., Baker, S.B. \& HewitT, V. (1964) Idiopathic paroxysmal myoglobinuria with acute renal failure and hypercalcemia. New England Journal of Medicine, 271, 283.

Turkington, R.N., Delcher, H.K., Neelon, F.A. \& GitelMAN, H.J. (1968) Hypercalcemia following acute renal failure. Journal of Clinical Endocrinology and Metabolism, 28, 1224.
Wilson, R., Raposo, C., Venkatesan, R., Lin, R., Thompson, A., Guha, A., Kramer, N. \& Parrish, A.E. (1973) Hypercalcemia during the diuretic phase of acute renal failure. Medical Annals of the District of Columbia, 42, 327.

Wu, B.C., Pillay, V.K., Hawker, C.D., Armbruster, K.F., SHAPIRO, H.S. \& ING, T.S. (1972) Hypercalcaemia in acute renal failure of acute alcoholic rhabdomyolysis. South African Medical Journal, 46, 1631.

\title{
Acute renal failure and hypoglycaemia due to sulphadiazine poisoning
}

\author{
A. W. CRafT \\ M.B. B.S., M.R.C.P. \\ J. T. BROCKLEBANK \\ M.B. B.S., M.R.C.P. \\ R. H. JACKSON \\ M.A., B.M., B.Ch., F.R.C.P. \\ Department of Child Health, Royal Victoria Infirmary, Newcastle upon Tyne NE1 4LP
}

\begin{abstract}
Summary
A 3-year-old girl is described who became oliguric and hypoglycaemic whilst receiving an excessive dose of sulphadiazine. The mechanism of the hypoglycaemia is discussed.
\end{abstract}

\section{Introduction}

Acute renal failure due to sulphonamide administration is now uncommon. This report describes a patient who became oliguric and hypoglycaemic whilst receiving treatment with an excessively high dose of sulphadiazine for meningococcal septicaemia.

\section{Case report}

A 3-year-old girl weighing $13 \mathrm{~kg}$ was admitted to another hospital, having been generally unwell for $12 \mathrm{hr}$, and then became comatose and developed a purpuric rash. Meningococcal septicaemia was subsequently proved when the organism was grown from the blood, but not from the cerebrospinal fluid. She was treated with i.v. fluids, hydrocortisone, penicillin and sulphadiazine $(450 \mathrm{mg} / \mathrm{kg}$ bodyweight $/ 24 \mathrm{hr}$ ). Her condition improved over the next $48 \mathrm{hr}$ and the dose of sulphadiazine was reduced

Correspondence: Dr A. W. Craft, Department of Child Health, The Royal Victoria Infirmary, Newcastle upon Tyne NE1 4LP. to $300 \mathrm{mg} / \mathrm{kg} / 24 \mathrm{hr}$. Urine output, having been normal, was noted to be much less on days 4 and 5 and because of the appearance of haematuria, the sulphadiazine was stopped. The blood urea was $12 \mathrm{mmol} / \mathrm{l}$ but the following day rose to $30 \mathrm{mmol} / 1$ and she was transferred to this hospital for further management. On admission she was found to be oedematous and semi-conscious. The blood urea was $30 \mathrm{mmol} / 1$, the sugar less than $1 \mathrm{mmol} / \mathrm{l}$, plasma insulin $22 \mathrm{mu} . / \mathrm{ml}$, plasma cortisol $800 \mathrm{nmol} / \mathrm{l}$ and the blood sulphonamide $700 \mathrm{mg} / \mathrm{l}$ (therapeutic level $120 \mathrm{mg} / \mathrm{l}$ ). Urine examination showed red cells and typical sulphadiazine crystals. She did not regain consciousness after infusion of $10 \mathrm{~g}$ of glucose. Peritoneal dialysis was commenced and her clinical condition slowly improved, the blood urea, glucose and sulphonamide levels reverting to normal as in Fig. 1. However, her urine output did not improve and cystoscopy revealed aggegations of sulphonamide deposits around both ureteric orifices. Bilateral ureteric catheters were inserted and a $2.5 \%$ sodium bicarbonate solution was infused at the rate of $2.5 \mathrm{ml} / \mathrm{hr}$ in each renal pelvis. Shortly afterwards, she began to pass large volumes of urine, the catheters were removed and she continued with an uneventful convalescence from her illness. At followup 2 months later she was physically and mentally normal, a ${ }^{51} \mathrm{Cr}$-EDTA clearance was $120 \mathrm{ml} / \mathrm{min} /$ $1.73 \mathrm{~m}^{2}$ and i.v. pyelogram was normal. 